\title{
CHIA PROTEIN CONCENTRATE (SALVIA HISPANICA L.) ANTI-INFLAMMATORY AND ANTIOXIDANT ACTIVITY
}

\author{
CÁRDENAS M ${ }^{1}$, CARPIO $\mathrm{C}^{1}$, WELBAUM J ${ }^{2}$, VILCACUNDO E ${ }^{3}$, CARRILLO $\mathrm{W}^{1 *}$ \\ ${ }^{1}$ Laboratory of Functional Foods, Faculty of Foods Science and Engineering, Technical University of Ambato, Ambato, Ecuador. \\ ${ }^{2}$ Department of Chemistry and Physics, West Texas A\&M University, Canyon, Texas, USA. ${ }^{3}$ Department of Research, Faculty of Health and \\ Human Science, Bolivar State University, Academic Campus, Guaranda, Ecuador. Email: wi.carrillo@uta.edu.ec
}

Received: 22 January 2016, Revised and Accepted: 03 May 2017

ABSTRACT

Objective: The objective of the study was to evaluate the antioxidant and anti-inflammatory activity of chia proteins concentrates in in vitro conditions.

Methods: Chia seeds (Salvia hispanica) were utilized to obtain chia protein concentrate at different pH 2.0, pH 3.0, pH 4.0, pH 5.0, and pH 6.0 using the isoelectric precipitation method and to evaluate the in vitro anti-inflammatory and in vitro inhibition of peroxidation lipid of chia protein concentrates.

Results: The best treatment to obtain chia protein concentrate was at pH 3.0 with a value of $25.53 \%$ yield using water as solvent and $38.13 \%$ yield using $\mathrm{NaCl} 1 \mathrm{M}$ as solvent. The higher protein content was found in the chia protein concentrate at pH 4.0 with values of $91.18 \%$ and $57.87 \%$ of protein content. All chia protein concentrates presented high in vitro anti-inflammatory activity and inhibition peroxidation lipid. Chia protein concentrate at $\mathrm{pH} 3.0(100-100 \mu \mathrm{g} / \mathrm{ml})$ presented anti-inflammatory activity with values ranging from $56.32 \%$ to $103.00 \%$ in a form dependent doses. Chia protein concentrate at $\mathrm{pH} 6.0$ presented a value range of $92.80-95.98 \%$ of inhibition of peroxidation lipid.

Conclusion: This study suggests that chia protein concentrates possess potent antioxidant and anti-inflammatory activities in in vitro conditions.

Keywords: Chia, Salvia hispanica L., Chia protein concentrate, Proteins.

(C) 2018 The Authors. Published by Innovare Academic Sciences Pvt Ltd. This is an open access article under the CC BY license (http://creativecommons. org/licenses/by/4. 0/) DOI: http://dx.doi.org/10.22159/ajpcr.2018.v11i2.17225

\section{INTRODUCTION}

The genus Salvia has around 900 species. The Lamiaceae chia seeds (Salvia hispanica L.) are a tropical and subtropical climates herbaceous plant which belongs to the family Lamiaceae and originated from southern Mexico and northern Guatemala. Food seeds have been important for human nutrition since 1500 BC [1,2]. Conventionally, chia seeds were used as food, in a wide range of traditional medicines, primary cosmetics, and as part of religious rituals in pre-Columbian civilizations [3]. Aztecs and Mayas used chia seeds in the preparation of folk medicines, food, and canvases. Chia seed composition is 32$39 \mathrm{~g} / 100 \mathrm{~g}$ oil, $26-41 \mathrm{~g} / 100 \mathrm{~g}$ of carbohydrates, $18-30 \mathrm{~g} / 100 \mathrm{~g}$ of dietary fiber, 4-6 g/100 g of ash, and 22-24 g/100 g protein contents. Chia seeds have an important content of vitamins, minerals, and antioxidants. Chemical composition and nutritional value of the chia seed can vary according to the climatic condition and location of growing [4]. In South America (Brazil, Ecuador, Bolivia, and Argentina), chia seeds are usually consumed mainly in the form of flour and seeds that can be added to preparations such as fruit, yogurt, cakes, and among others. At present, its consumption has increased due to its beneficial effects related to obesity, cardiovascular diseases, diabetes, and some types of cancer. Free radicals, and different species of free radicals, are reactive oxygen species (ROS) such as $\mathrm{O}_{2}, \mathrm{H}_{2} \mathrm{O}_{2}$, and $\mathrm{OH}^{-}$. ROS produce oxidative damage in human body and biochemical compounds such as enzymes. Oxidative stresses can be a cause of different diseases such as diabetes, arteriosclerosis, thrombosis, inflammation, and various types of cancers [5-7]. Synthetic antioxidants such as butylated hydroxyanisole (BHA) and butylated hydroxytoluene (BHT) are used as food additives and preservatives [8,9]. However, due to the possible toxic and carcinogenic effects associated to BHT and BHA, research is being conducted to find natural sources $[10,11]$. Medicinal plants have been utilized for millennia by humans, because these plants have phytochemical components for the prevention and treatment of different diseases and ailments such as inflammation processes. Food proteins have antioxidant and anti-inflammatory activity. Hen egg white lysozyme presents antioxidant activity when ORAC and thiobarbituric acid reactive substances (TBARS) methods are used. Hen egg white lysozyme presents anti-inflammatory activity in mice with a reduction of edema paw $[12,13]$. The aim of this work was to obtain chia protein concentrate and evaluate its in vitro antioxidant and anti-inflammatory activity.

\section{METHODS}

\section{Defatted chia flour (DCF) preparation}

DCF was produced according to the method of Sze-Tao and Sathe [14]. Chia (S. hispanica L.) seeds were purchased from the supermarket shelves in Ecuador. Walnuts were ground in a windmill. The flour was defatted with hexane (flour/hexane ratio of 1:10 [w/v]) under constant magnetic stirring for $3 \mathrm{~h}$. The slurry was vacuum filtered through a paper filter and the residue was used for subsequent extraction. Hexane extractions were repeated until the filtrate was clear. Residue from the last extraction and filtration step was air dried in a fume hood. DTF was stored at $-20^{\circ} \mathrm{C}$ until further use.

\section{Preparation of protein isolates from chia seeds}

Chia protein concentrate was prepared according to the process described by Barrio and Añón [15] with minor modifications. DCF was extracted by stirring for $2 \mathrm{~h}$ at room temperature (about $25^{\circ} \mathrm{C}$ ) with deionized water adjusted to $\mathrm{pH} 8.0$ with $1 \mathrm{M} \mathrm{NaOH}$ (flour:water ratio, $1: 20[\mathrm{w} / \mathrm{v}])$. The slurry was centrifuged at $5000 \mathrm{~g}$ for $30 \mathrm{~min}$ at $25^{\circ} \mathrm{C}$ in an Eppendorf centrifuge (USA). The insoluble chia protein pellet was reslurried with $\mathrm{pH}$ adjusted deionized water as above and centrifuged again. The supernatants mixed together were adjusted to $\mathrm{pH} 3.0$; $\mathrm{pH} 4.0$; pH 5.0; and pH 6.0 (isoelectric point), kept for $48 \mathrm{~h}$ at $4^{\circ} \mathrm{C}$ with $1 \mathrm{M} \mathrm{HCl}$ and subsequently centrifuged at $5000 \mathrm{~g}$ for $30 \mathrm{~min}$ at the same temperature. The precipitate was washed with deionized water, resolubilized in deionized water, neutralized to $\mathrm{pH} 7$ with $1 \mathrm{M} \mathrm{NaOH}$ 
at room temperature, then dialyzed against water and lyophilized. All lyophilized protein samples were stored in airtight plastic bottles at $-20^{\circ} \mathrm{C}$ until further use.

\section{Proximate analysis of chia seeds proteins}

Protein, moisture, fat, ash, and fiber contents were determined according to AOAC methods [16], numbers 920.152, 950.46, 930.09, 920.153, and 934.10, respectively. Determination of soluble solids of the materials was made according to the ISO 2173:2003 method [17]. The protein contents of samples were determined by the microKjeldahl method (AACC, 2000) using a protein-nitrogen coefficient of 6.25. Carbohydrates were determined according to the Zhu et al. [18] method. The contents were expressed on a dry weight basis. Each analysis was carried out in triplicate, and data were reported as means \pm standard deviation

\section{Sodium dodecyl sulfate-polyacrylamide gel electrophoresis (SDS-PAGE)}

SDS-PAGE electrophoresis of chia (S. hispanica L.) proteins, proteins fractions, and finally products of enzymatic hydrolysis of proteins, was carried out according to the method proposed by Laemmli [19]. Runs were performed in mini-protean (Bio-Rad, Hercules, CA, USA). In SDS-PAGE system gels of $12 \mathrm{~g}$ acrylamide $/ 100 \mathrm{~mL}$ of resolving gel and $4 \mathrm{~g}$ acrylamide $/ 100 \mathrm{~mL}$ of stacking gels were used. Relative molecular masses of protein were determined by comparison to the molecular weight marker with polypeptide SDS-PAGE standard (MW 6.5-200 kDa) (Bio-Rad) kDa GE Healthcare Life Sciences. Gels were fixed and stained with Coomassie Brilliant Blue G-250 (Sigma-Aldrich, St. Louis, MO) for $16 \mathrm{~h}$.

\section{Evaluation of in vitro anti-inflammatory activity}

Anti-inflammatory activity of chia protein concentrate at $\mathrm{pH} 2.0$, $\mathrm{pH} 3.0, \mathrm{pH} 4.0, \mathrm{pH} 5.0$, and $\mathrm{pH} 6.0$ was evaluated with the protein denaturation method $[20,21]$. Diclofenac sodium, a powerful nonsteroidal anti-inflammatory drug (NSAID), was used as a standard drug. The reaction mixture consisting of $2 \mathrm{~mL}$ of different concentrations of protein concentrate $(100-1000 \mu \mathrm{g} / \mathrm{mL})$ or standard diclofenac sodium (100 and $1000 \mu \mathrm{g} / \mathrm{mL}$ ) and $2.8 \mathrm{~mL}$ of phosphate-buffered saline (pH 6.4) was mixed with $2 \mathrm{~mL}$ of egg albumin (from fresh hen egg) and incubated at $27^{\circ} \mathrm{C}$ for $15 \mathrm{~min}$. Denaturation was induced by keeping the reaction mixture at $70^{\circ} \mathrm{C}$ in a water bath for $10 \mathrm{~min}$. After cooling, the absorbance was measured at $660 \mathrm{~nm}$ using double-distilled water as blank. Each experiment was done in triplicate and the average was calculated. The percentage inhibition of protein denaturation was calculated using the following formula: \% inhibition of protein denaturation $=1-(\mathrm{At}-\mathrm{Ac} / \mathrm{Ac}) \times 100$

\section{TBARS assay}

Chia protein concentrate were used to evaluate the inhibition of lipid peroxidation. At $0.5 \mathrm{~g}$ of olive oil was rusty by heat at $65^{\circ}$ during 8 days, after were added Chia protein concentrate until to obtain at concentrations of $0.02 ; 0.04 ; 0.1$; and $0.2 \mathrm{mg} / \mathrm{mL}$ of milk proteins and were incubated at $30^{\circ} \mathrm{C}$ during $24 \mathrm{~h}$. BHT was used such as positive control at concentrations of $0.02 ; 0.04 ; 0.1$; and $0.2 \mathrm{mg} / \mathrm{mL}$ of BHT. Olive oil without sample (antioxidant) was used such negative control. $1 \mathrm{~mL}$ of sample was mix with $1 \mathrm{~mL}$ of the $1 \%$ TBA, the solution was heated at $95^{\circ} \mathrm{C}$ during $1 \mathrm{~h}$, and cooled down during $15 \mathrm{~min}$. Then, absorbance of the final solution containing milk digests was measured at $532 \mathrm{~nm}$ using a spectrophotometer (Thermo Scientific Evolution 200). The decrease of absorbance indicates an increase of antioxidant activity. The values of antioxidant activity were expressed as the percentage of inhibition of lipid peroxidation in larvae homogenate as follows: \% inhibition of lipid peroxidation $=(1-[\mathrm{Ab}-\mathrm{As}] / \mathrm{Ab} \times 100)$, where $\mathrm{Ab}$ is the absorbance of blank and As is the absorbance of the sample [22]

\section{Statistical analysis}

Results are presented as means \pm standard deviation from three replicates of each experiment. Differences between mean values were determined by the analysis of variance (ANOVA). The post hoc analysis was performed by the Tukey test. All tests were considered significant at $p<0.05$. Statistical analysis was performed using the software package Prism 4 for Windows, version 6.0 (GraphPad Software Inc., www.graphpad.com).

\section{RESULTS}

\section{Proximate analysis}

The results of proximate analysis of chia flour and chia protein concentrate obtained at $\mathrm{pH} 4.0$ are shown in Table 1. Chia flour has a content of protein of $19.78 \%$ compared to the chia protein concentrate of Ecuador with a content of $61.32 \%$ of protein measured using the Kjeldahl method. Carbohydrates content in chia flour were $31.46 \%$ of total content. Chia protein concentrates present $21.74 \%$ of carbohydrates showing that this biomolecule presence decreased. Lipid content of chia flour was of $16.06 \%$ of lipid compared to the lipid content of chia protein concentrate, which had a $9.63 \%$ content of lipid after being defatted with hexane. Lipid content decreased in chia protein concentrate. Ullah et al., 2015 reported a protein content ranging between $15 \%$ and $25 \%$ in chia seeds. Our value is in between these limits [23]. The protein content of chia seed grown in different habitats ranges from $18.8 \%$ to $21.5 \%$. The variation in protein content was probably due to agronomic, climatic, and soil conditions [24]. The content of fat in the chia seeds was $16.06 \%$. Ixtaina et al., 2008 reported $30-33 \%$ of fat in chia seeds. Our value is lower than that value. In Argentina, different values of content of oil in chia have been reported with values ranging $32.2-36.8 \%$ compared to $35.6-38.6 \%$ [25]. The difference in oil content could be connected to the difference in climatic conditions, agronomic practices, fertilization regimes, irrigation practices, etc. [26]. The higher values of tocopherols can have a positive impact on the storage stability of chia oil. Content of fiber was $27.88 \%$. Protein, lipids, and fiber are biocompounds having a good acceptance among consumers. European Union has accepted chia as a functional food. Chia seeds are considered to be safer without the harmful effects on health. Chia seeds can be used in baked goods, nutritional supplements, cereal bars, cookies, bread, snacks, etc. Chia seeds are used as a component of several foods in Mexico, Argentina, Chile, Ecuador, Canada, USA, and Japan and are also used for different purposes. The USA dietary guidelines recommend consuming chia seeds for health reasons as a primary source of good food. Chia sprouts are used in salads, chia seeds are also used in beverages, cereal based foods, and finally chia seeds can be consumed in raw form [27].

\section{Yield of chia protein concentrate}

Table 2 summarizes yield of chia protein concentrate obtained using water and $\mathrm{NaCl}$ as solvents to isoelectric precipitation. Chia seeds were used in our study to obtain the chia defatted flour. The defatted chia flour was used to obtain chia concentrate protein using the isoelectric precipitation method at different $\mathrm{pHs}(\mathrm{pH} 2.0 ; \mathrm{pH} 3.0 ; \mathrm{pH} 4.0 ; \mathrm{pH} 5.0$; and $\mathrm{pH}$ 6.0) with water as solvent. The highest yield was obtained at

Table 1: Proximate analysis of chia flour and chia protein concentrate at $\mathrm{pH} 4.0$

\begin{tabular}{|c|c|c|c|c|c|c|}
\hline Content (\%) & Protein & Lipid & Carbohydrates & Fiber & Moisture & Ash \\
\hline Flour & $19.78 \pm 0.015^{\mathrm{a}}$ & $16.06 \pm 0.038^{\mathrm{b}}$ & $31.46 \pm 0.062^{c}$ & $27.88 \pm 0.021^{\mathrm{d}}$ & $5.71 \pm 0.032^{\mathrm{e}}$ & $4.82 \pm 0.025$ \\
\hline Concentrate $\mathrm{pH} 4.0$ & $61.32 \pm 0.019^{g}$ & $9.63 \pm 0.025^{\mathrm{h}}$ & $21.74 \pm 0.005^{\mathrm{i}}$ & $0.52 \pm 0.003^{j}$ & $2.86 \pm 0.011^{\mathrm{k}}$ & $3.93 \pm 0.020^{1}$ \\
\hline
\end{tabular}

Results represent the average of three determinations of \pm SD ( $n=3)$. Different letters show statistical difference between the groups (p<0.05) ANOVA and Tukey's test

SD: Standard deviation 
$\mathrm{pH} 3.0$ with a value of $25.53 \%$ using water solvent and $38.13 \%$ using $\mathrm{NaCl}$ solvent. Yields for $\mathrm{pH} 2.0$ and $\mathrm{pH} 3.0$ with water solvent presented no statistical differences. Yields for $\mathrm{pH} 3.0, \mathrm{pH} 4.0$, and $\mathrm{pH} 6.0$ with $\mathrm{NaCl}$ solvent present no statistical differences with $\mathrm{p}<0.05$. The contents of protein in the chia seed concentrate protein were analyzed using the Biuret and BCA methods. The treatment at $\mathrm{pH} 4.0$ presented a higher content of protein with both methods with a $91.81 \%$ obtained by Biuret method and a $57.87 \%$ obtained by BCA method (Table 3 ). For all pHs, there are statistical differences with $\mathrm{p}<0.05$ when both methods are compared. These differences can be fundamental in the measurement of each method. The Biuret method consists of the formation of purple complexes between $\mathrm{Cu}^{+2}$ and the amine group of the peptide bonds $\left(\mathrm{NH}_{2}\right)$. The BCA method is based on the measure of $\mathrm{Cu}^{+1}$ formatted for the purple complex produced by the reduction of $\mathrm{Cu}^{+2}$ by the peptide bonds into $\mathrm{Cu}^{+1}$.

\section{SDS-PAGE electrophoresis}

All chia protein concentrates were analyzed by SDS-PAGE electrophoresis. The gel of polyacrylamide shows the bands of chia protein concentrate obtained with water solvent. The range of molecular weights is between 40 and $70 \mathrm{kDa}$. All the concentrates of chia present the same profile of proteins with identical bands. All the bands present high expression at all pHs tested. The majority of the bands identified were globulins and albumins (Fig. 1).

\section{In vitro anti-inflammatory activity}

The inhibitory effect at different concentrations of chia protein concentrate using the protein denaturation method is shown in Table 4. The chia protein concentrates obtained at $\mathrm{pH} 2.0, \mathrm{pH} 3.0, \mathrm{pH} 4.0$, $\mathrm{pH} 5.0$, and $\mathrm{pH} 6.0$ were tested at $100-1000 \mu \mathrm{g} / \mathrm{ml}$ concentration. Diclofenac at $100-1000 \mu \mathrm{g} / \mathrm{ml}$ concentration was used as a positive

Table 2: Percentage of yield of chia protein concentrate obtained with water and $\mathrm{NaCl}(1 \mathrm{M})$ solvents

\begin{tabular}{lll}
\hline Sample & \multicolumn{2}{l}{ Solvents } \\
\cline { 2 - 3 } & Water (\%) & NaCl 1M (\%) \\
\hline pH 2.0 & $24.82 \pm 0.757^{\mathrm{d}}$ & $28.21 \pm 0.726^{\mathrm{c}}$ \\
pH 3.0 & $25.53 \pm 0.911^{\mathrm{d}}$ & $38.13 \pm 0.148^{\mathrm{a}}$ \\
pH 4.0 & $12.30 \pm 0.238^{\mathrm{g}}$ & $38.03 \pm 0.698^{\mathrm{a}}$ \\
pH 5.0 & $19.12 \pm 0.743^{\mathrm{e}}$ & $34.73 \pm 0.103^{\mathrm{b}}$ \\
pH 6.0 & $14.62 \pm 0.186^{\mathrm{f}}$ & $37.40 \pm 0.326^{\mathrm{a}}$ \\
\hline
\end{tabular}

Results represent the average of three determinations of $\pm S D(n=3)$. Different

letters show statistical difference between the groups $(\mathrm{p}<0.05)$ ANOVA and

Tukey's test. SD: Standard deviation control, diclofenac being a strong anti-inflammatory medicine of the AINES (anti-inflammatory non-steroid or NSAIDs in the US) type. Table 4 summarizes a significant inhibition of denaturation of egg albumin on a concentration-dependent manner. The positive control diclofenac sodium presented a high anti-inflammatory activity with values of $46.97-100.00 \%$ of inhibition of denatured protein. The effect was dependent on doses. The in vitro anti-inflammatory activity of chia proteins concentrate was comparable to the diclofenac sodium anti-inflammatory activity. Chia protein concentrate at $\mathrm{pH} 2.0$ was the most effective sample reducing the percentage of denature protein. The effect was dependent on doses. Chia protein concentrate also presented a high activity with values between $60.97 \%$ and $97.66 \%$ of inhibition of denatured protein. Chia protein concentrate at $\mathrm{pH} 6.0$ presented $106.98 \%$ of anti-inflammatory activity compared to the positive control, diclofenac sodium.

\section{Inhibition of peroxidation lipid (TBARS)}

In vitro antioxidant activity of chia protein concentrate was evaluated using the TBARS method. Chia protein concentrate at $\mathrm{pH} 2.0, \mathrm{pH} 3.0$, $\mathrm{pH} 4.0, \mathrm{pH} 5.0$, and $\mathrm{pH} 6.0$ at concentrations of 100, 200, 500, and $1000 \mu \mathrm{g} / \mathrm{ml}$ were used. Synthetic antioxidant BHT was used as positive control for all assays at concentrations of $100,200,500$, and $1000 \mu \mathrm{g} / \mathrm{ml}$. BHT presented high antioxidant activity with values between $93.94 \%$ and $97.43 \%$ of inhibition of lipid peroxidation. This antioxidant activity was dependent on doses, the higher the dose the higher concentrations, and hence, the higher antioxidant activity. All chia protein concentrate samples presented a high antioxidant activity with values ranging 86.97-95.98\% of inhibition of lipid peroxidation on a dependent doses effect. Chia protein concentrate at $\mathrm{pH} 6.0$ was the most effective sample to inhibit the lipid peroxidation with values ranging $92.80-95.98 \%$ of inhibition of lipid peroxidation using the TBARS method (Table 5).

\section{DISCUSSION}

In vitro and in vivo studies on inflammation have become the focus of global scientific research dye to its implication in important to all human and animal diseases or aliments. Plant-based drugs used in the practice of traditional treatment of many diseases including inflammation have become the objective of current research because the plants are easy production, cheap, and have a big therapeutic potential. They can be included in the diet of human and animals. The NSAIDs possess antiinflammatory action for treatment of many inflammatory conditions such as rheumatoid arthritis, osteoarthritis, and musculoskeletal disorders, but the continuous use of NSAIDs has some associated negative effects such as nausea, fluid retention, bleeding, and gastric lesion (gastric ulcer and gastritis) [28,29]. For this reason, new anti-

Table 3: Content of protein of chia protein concentrate using Biuret and BCA method

\begin{tabular}{lllll}
\hline Protein (\%) & pH 2.0 & pH 3.0 & pH 4.0 & pH 5.0 \\
\hline Biuret & $61.21 \pm 1.705^{\mathrm{d}}$ & $81.03 \pm 2.385^{\mathrm{c}}$ & $91.81 \pm 2.092^{\mathrm{a}}$ & $89.05 \pm 3.057^{\mathrm{ab}}$ \\
BCA & $45.10 \pm 1.429^{\mathrm{c}}$ & $44.91 \pm 2.041^{\mathrm{c}}$ & $57.87 \pm 1.830^{\mathrm{a}}$ & $84.89 \pm 1.063^{\mathrm{bc}}$ \\
\hline
\end{tabular}

Results represent the average of three determinations of \pm SD $(n=3)$. Different letters show statistical difference between the groups ( $<<0.05)$ ANOVA and Tukey's test. SD: Standard deviation

Table 4: In vitro anti-inflammatory activity of chia protein concentrate using denaturation of albumin protein method

\begin{tabular}{|c|c|c|c|c|}
\hline \multirow[t]{2}{*}{ Inhibition (\%) } & \multicolumn{4}{|c|}{ Concentrations } \\
\hline & $100 \mu \mathrm{g} / \mathrm{ml}$ & $200 \mu \mathrm{g} / \mathrm{ml}$ & $500 \mu \mathrm{g} / \mathrm{ml}$ & $1000 \mu \mathrm{g} / \mathrm{ml}$ \\
\hline Diclofenac & $47.46 \pm 0.523^{\mathrm{a}}$ & $77.64 \pm 0.485^{\mathrm{a}}$ & $98.34 \pm 0.159^{\mathrm{a}}$ & $100.00 \pm 0.558^{\mathrm{a}}$ \\
\hline pH 2.0 & $56.32 \pm 0.653^{b}$ & $69.22 \pm 0.405^{\mathrm{b}}$ & $80.57 \pm 0.211^{\mathrm{b}}$ & $103.00 \pm 0.670^{\mathrm{a}}$ \\
\hline pH 3.0 & $60.97 \pm 0.388^{c}$ & $68.31 \pm 0.239^{b}$ & $74.94 \pm 0.575^{c}$ & $97.66 \pm 0.138^{a}$ \\
\hline pH 4.0 & $54.00 \pm 0.138^{\mathrm{d}}$ & $54.41 \pm 0.211^{\mathrm{c}}$ & $56.04 \pm 0.833^{\mathrm{d}}$ & $58.76 \pm 0.239^{b}$ \\
\hline pH 5.0 & $50.36 \pm 0.319^{\mathrm{e}}$ & $53.33 \pm 0.211^{\mathrm{c}}$ & $53.79 \pm 0.239^{e}$ & $69.75 \pm 0.211^{c}$ \\
\hline pH 6.0 & $43.76 \pm 0.211^{\mathrm{f}}$ & $45.49 \pm 0.159^{d}$ & $67.19 \pm 0.780^{\mathrm{f}}$ & $106.98 \pm 0.211^{\mathrm{a}}$ \\
\hline
\end{tabular}

Data are expressed as the mean \pm SD $(n=3)$. Values in the same column having different letters differ significantly ( $<<0.05)$. ANOVA and Tukey's test, SD: Standard deviation 
Table 5: Inhibition of peroxidation lipid (TBARS) of chia protein concentrate. Time of incubation $24 \mathrm{~h}$

\begin{tabular}{llll}
\hline Inhibition (\%) & \multicolumn{2}{l}{ Concentrations } & \\
\cline { 2 - 3 } & $\mathbf{1 0 0} \boldsymbol{\mu} \mathbf{g} / \mathbf{m l}$ & $\mathbf{2 0 0} \boldsymbol{\mu g} / \mathbf{m l}$ & $\mathbf{5 0 0} \boldsymbol{\mu g} / \mathbf{m l}$ \\
\hline BHT & $93.94 \pm 0.034^{\mathrm{a}}$ & $94.05 \pm 0.056^{\mathrm{a}}$ & $96.18 \pm 0.032^{\mathrm{a}}$ \\
pH 2.0 & $86.97 \pm 0.278^{\mathrm{b}}$ & $91.45 \pm 0.382^{\mathrm{b}}$ & $95.01 \pm 0.201^{\mathrm{a}}$ \\
pH 3.0 & $90.86 \pm 0.041^{\mathrm{c}}$ & $91.09 \pm 0.077^{\mathrm{b}}$ & $92.63 \pm 0.089^{\mathrm{b}}$ \\
pH 4.0 & $91.55 \pm 0.188^{\mathrm{c}}$ & $91.84 \pm 0.107^{\mathrm{b}}$ & $92.36 \pm 0.118^{\mathrm{b}}$ \\
pH 5.0 & $91.75 \pm 0.244^{\mathrm{c}}$ & $92.30 \pm 0.036^{\mathrm{b}}$ & $95.42 \pm 0.219^{\mathrm{b}}$ \\
pH 6.0 & $92.80 \pm 0.265^{\mathrm{c}}$ & $94.51 \pm 0.056^{\mathrm{a}}$ & $92.51 \pm 0.015^{\mathrm{b}}$ \\
\hline
\end{tabular}

Data are expressed as the mean \pm SD $(n=3)$. Values in the same column having different letters differ significantly ( $<<0.05)$. ANOVA and Tukey's test. SD: Standard deviation, TABRS: Thiobarbituric acid reactive substances, BHT: Butylated hydroxytoluene

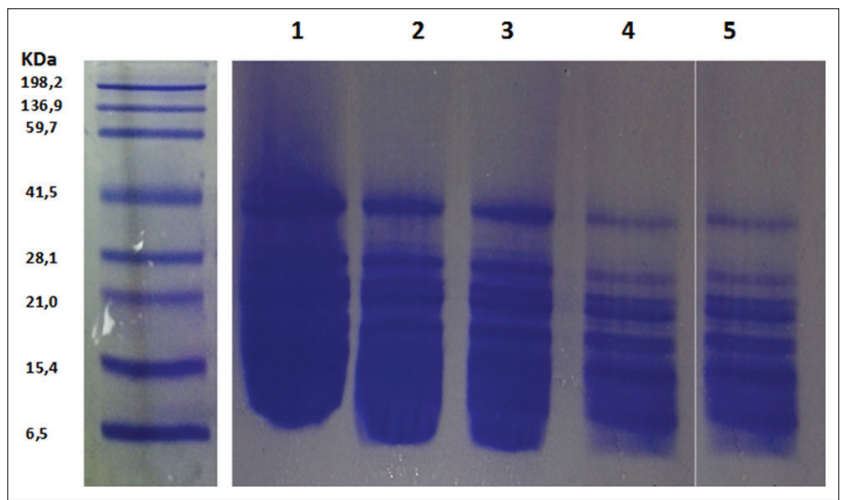

Fig. 1: Sodium dodecyl sulfate-polyacrylamide gel electrophoresis of chia protein concentrate. Lane 1: Chia protein concentrate at pH 2.0, lane 2: Chia protein concentrate at pH 3.0, lane 3: Chia protein concentrate at $\mathrm{pH} 4.0$, lane 4 : Chia protein concentrate at pH 5.0, and lane 5: Chia protein concentrate at pH 6.0

inflammatory drugs without these side effects are being researched such as alternatives to NSAID without a lot of side effects associated with the use of drugs synthetic such as diclofenac and ibuprofen.

Chen et al. [30] have reported fish and shellfish protein hydrolysate with high capacity to inhibit lipid peroxidation. These peptides are considered good candidates in search of effective non-toxic substances with differing antioxidant mechanisms. Even though the exact mechanism of peptides to act as an antioxidant is not clearly known, some aromatic amino acids and histidine are reported to play a key role in this activity. Proteins have been shown to have antioxidative activities against the peroxidation of lipids and/or fatty acids on hydrolysis. Chen et al., 1995 [31] reported six antioxidative peptides from the proteolytic digests of a soybean protein. Chen et al., 1996 reported that a small peptide with the sequence LeuLeu-Pro-His-His was used to obtain 28 synthetic peptides and their antioxidative activities against the peroxidation of linoleic acid were compared in an aqueous system [32]. In this study, chia protein was effective to inhibit lipid peroxidation of olive oil. The result of this study could explain the efficiency in medicinal use of these proteins of chia for the antioxidant and anti-inflammation purpose.

\section{CONCLUSION}

Chia seeds (S. hispanica) have a good proportion of protein to obtain using the isoelectric method at different pHs to collect chia protein concentrate. Chia protein concentrate presents a high in vitro antiinflammatory activity and inhibition peroxidation lipid. Chia seeds can be used to obtain vegetal proteins with biological activities. Chia proteins can be used as ingredients to elaborate functional foods. Chia proteins can be a good source of vegetal protein in Ecuador.

\section{ACKNOWLEDGMENTS}

This study was supported by Universidad Técnica de Ambato, Ecuador (Project CPU-1373-2014-UTA). Project: Valorización de la calidad nutricional y funcional de alimentos tradicionales de la población ecuatoriana. Red de Cereales de la Red de Universidades del Ecuador (REDU) and Project Canje de Deuda España-Ecuador. This work has been reviewed in the English edition by Emilio Labrador.

\section{REFERENCES}

1. Ayerza R. Coates. W. Effect of dietary $\alpha$-linolenic fatty acid derived from chia when fed as ground seed. Whole seed and oil on lipid content and fatty acid composition of rat plasma. Ann Nutr Metab 2007;51:27-34.

2. Ayerza R. Coates W. Composition of chia (Salvia hispanica) grown in six tropical and subtropical ecosystems of South America. Trop Sci 2004;44:131-5.

3. Coates W. Ayerza R. Chia (L.) seed as an n-3 fatty acid source for finishing pigs: Effects on fatty acid composition and fat stability of the meat and internal fat. Growth performance. And meat sensory characteristics. J Anim Sci 2009;87:3798-804.

4. Coates W. Protein content. Oil content and fatty acid profiles as potential criteria to determine the origin of commercially grown chia (Salvia hispanica L.). Ind Crop Prod 2011;34:1366-71.

5. Halliwell B. Biochemistry of oxidative stress. Biochem Soc Trans 2007;35:1147-50.

6. Khlebnikov AI, Schepetkin IA, Domina NG, Kirpotina LN, Quinn MT. Improved quantitative structure-activity relationship models to predict antioxidant activity of flavonoids in chemical, enzymatic, and cellular systems. Bioorg Med Chem 2007;15:1749-70.

7. Carocho M, Ferreira IC. A review on antioxidants, prooxidants and related controversy: Natural and synthetic compounds, screening and analysis methodologies and future perspectives. Food Chem Toxicol 2013;51:15-25.

8. Dávalos A, Gómez-Cordóves C, Bartolomé B. Extending applicability of the oxygen radical absorbance capacity (ORAC-fluorescein) assay. J Agric Food Chem 2004;52:48-54.

9. Contreras MM, Hernández-Ledesma B, Amigo L, Martín-Álvarez PJ, Recio I. Production of antioxidant hydrolyzates from a whey protein concentrate with thermolysin: Optimization by response surface methodology. LWT Food Sci Technol 2011;44:9-15.

10. Mann B, Kumari A, Kumar R, Sharma R, Prajapati K, Mahboob S, et al. Antioxidant activity of whey protein hydrolysates in milk beverage system. J Food Sci Technol 2015;52:3235-41.

11. Cai L, Wu X, Lv Y, Xu Y, Mi G, Li J, et al. The neuroprotective and antioxidant activities of protein hydrolysates from grass carp (Ctenopharyngodon idella) skin. J Food Sci Technol 2015;52:3750-5.

12. Carrillo W, Gómez-Ruiz JA, Miralles B, Ramos M, Barrio D, Recio I. Identification of antioxidants peptides of hen egg white lysozyme and evaluation of inhibition of lipid peroxidation and cytotoxicity in the zebrafish model. Eur Food Res Technol 2016;242:1777-1785.

13. Carrillo W, Spindola H, Ramos M, Recio I, Carvalho JE. Antiinflammatory and anti-nociceptive activities of native and modified hen egg white lysozyme. J Med Food 2016;19:978-82.

14. Sze-Tao KW, Sathe SK. Walnuts (Juglans regia L.) Proximate composition, protein solubility, protein amino acid composition and protein in vitro digestibility. J Sci Food Agric 2000;80:1393-401.

15. Barrio DA, Añón MC. Potential antitumor properties of a protein isolate obtained from the seeds of Amaranthus mantegazzianus. Eur J Nutr 2010;49:73-82.

16. Association of Analytical Communities International. Official Methods of Analysis of AOAC. $17^{\text {th }}$ ed. Gaithersburg, MD, USA: AOAC International; 2000. 
17.. Fruits and Vegetable Products. Determination of Soluble SolidsRefractometric Method. Geneva: International Organization for Standardization; 2003.

18. Zhu KX, Zhou HM, Qian HF. Proteins extracted from defatted wheat germ: Nutritional and structural properties. Cereal Chem 2006;83:69-75.

19. Laemmli UK. Cleavage of structural proteins during the assembly of bacteriophage T4. Nature 1970;227:680-5.

20. Padmanabhan P, Jangle SN. Evaluation of in-vitro anti-inflammatory activity of herbal preparation, a combination of four medicinal plants. Int J Basic Appl Med Sci 2012;1:109-16.

21. Sangita C, Priyanka C, Protapaditya D, Sanjib B. Evaluation of in vitro anti-inflammatory activity of coffee against the denaturation of protein. Pac J Trop Biomed 2012;2:S178-80.

22. Carrillo W, Tubón J. Digestibility and enzymatic activity in vitro of hen egg white lysozyme. Asian J Pharm Clin Res 2016;9:376-8.

23. Ullah R, Nadeem M, Khalique A, Imran M, Mehmood S, Javid A, et al. Nutritional and therapeutic perspectives of chia (Salvia hispanica L.): A review. J Food Sci Technol 2016;53:1750-8.

24. Peiretti PG, Ga F. Fatty acid and nutritive quality of chia (Salvia hispanica L.) seeds and plant during growth. Anim Feed Sci Technol 2009;148:267-75.

25. Ixtaina VY, Nolasco SM, Tomas MC. Physical properties of chia (Salvia hispanica L.) seeds. Ind Crop Prod 2008;28:286-93.
26. Ayerza R. Seed yield components, oil content, and fatty acid composition of two cultivars of moringa (Moringa oleifera Lam.) growing in the arid Chaco of Argentina. Ind Crop Prod 2011;33:389-94.

27. Reyes-Caudillo E, Tecante A, Valdivia-López MA. Dietary fibre content and antioxidant activity of phenolic compounds present in Mexican chia (Salvia hispanica L.) seeds. Food Chem 2008;107:656-63.

28. Abualhasan M, Assali M, Jaradat N, Tarayra R, Hamdan A, Ardah R, et al. Synthesis and formulation of ibuprofen pro-drugs for enhanced transdermal absorption. Int J Pharm Pharm Sci 2014;7:352-4.

29. Zupanets IA, Shebeko SK, Popov OS. The effect of the medication "diclocor", containing diclofenac and quercetin, on clinico-biochemical parameters in rats with osteoarthritis. Int $\mathrm{J}$ Pharm Pharm Sci 2015;7:101-4

30. Chen HM, Muramoto K, Yamauchi F, Fujimoto K, Nokihara K. Antioxidative properties of histidine-containing peptides designed from peptide fragments found in the digests of a soybean protein. J Agric Food Chem 1998;46:49-53.

31. Chen HM, Muramoto K, Yamauchi F. Structural analysis of antioxidative peptides from soybean â-conglycinin. J Agric Food Chem 1995;43:574-8.

32. Chen HM, Muramoto K, Yamauchi F, Nokihara K. Antioxidant activity of designed peptides based on the antioxidative peptide isolated from digests of a soybean peptide. J Agric Food Chem 1996;44:2619-23. 